\title{
The Impact of the Financial Crisis on the Constitutional Form of Goverment and Democracy. Some Lessons from Italy
}

\author{
Andrea Simoncini \\ Professore Ordinario \\ Universidad de Florencia
}

\begin{abstract}
Summary: Introduction.-1. The theories.-2. My view.-3. The decline of contemporary European constitutionalism: «return to the Statuto»? - 4. Impact on parliamentary forms of government. 4.1. Flexibilisation of the system of legal sources. 4.2. Flexibilisation of the regulation of economic policy. 4.3. Flexibilisation of the role of the President of the Republic.-5. Effects on regionalism. 5.1. Flexibilisation of the constitutional division of powers between central state and regions. - 6. The economic crisis and democracy. 6.1. Loss of trust in democratic institutions.
\end{abstract}

\section{INTRODUCTION}

\section{THE THEORIES}

Many of the theories on the current conditions of national constitutional states and of the European Union may be summarized thus: the present economic crisis is clearly impairing the soundness of the guarantees and limits provided by constitutional law (at both national and European levels).

More specifically, the efforts to remedy the devastating effects of the crisis led to the adoption of measures, and the creation of institutions (at both national and European levels) which -in concrete terms- did not fall within the scope of constitutional legitimacy, or at least raised serious doubts on the «principle of constitutional rigidity» ${ }^{1}$. As a consequence, today national and European institutions are in fact governed by «rules» or subjected to «authorities» that are different from, or external to, the very constitutional system that established them.

This analysis usually yields two possible scenarios.

The first may be defined the «resilience of constitutional structures». In this case, once the «extra ordinem» stage has ended, the powers return within «ordinem». The priority is to focus on solving the crisis by addressing its

${ }^{1}$ F. Angelini, M. Benvenuti (a cura di), Il diritto costituzionale alla prova della crisi economica. Atti del Convegno di Roma, 26-27 aprile 2012, Naples, Jovene, 2012, passim. 
economic-financial causes, seeking to curtail its duration and therefore its distorting effects, rather than on issues of constitutionality.

The second is the scenario of «irreversible deformation»: the damage done by the extra ordinem phase is irreversible and thus tends to produce stable results.

In this case, the priority is to focus on legal-institutional aspects and to establish «counter-measures» to avert the disappearance of both constitutional rigidity and constitutional values.

A sort of «third position», encompassing elements of both scenarios discussed above, was recently proposed: a «ius-stitium» (Agamben ${ }^{2}$, Cartabia), the creation of a «temporary constitutional law», a constitutional amendment that establishes a different regime in times of crisis. Guarantees are therefore not entirely forgone, but those which are not essential are attenuated; thus, the emergency phase which, in the first and second cases above, would simply «non habet legem», is governed at least to some extent.

\section{MY VIEW}

The following observations presume a different starting point.

Indeed, I believe that the current economic crisis is not the cause of the damage suffered by constitutional systems.

I believe that the causes of these transformations or deformations predate the 2008 economic crisis, and are due to reasons that are much deeper and more structural than the urgent need to establish extra-ordinem measures and institutions to fight the financial crisis, which by now has also heavily affected sovereign debts.

In my opinion, if the crisis has had a role, it was that of «accelerating» this structural decline or of «triggering» latent tensions. It acted upon the magnitude of phenomena, therefore, but not on their quality.

However, the crisis did «add» a specific contribution in one respect. It introduced a new factor into the complex evolution of contemporary (national and European) constitutional systems: the crisis of the overall legitimacy of public institutions, of their reliability. I will come to this later.

A non-secondary consequence of my theory is that, while making every effort to resolve the financial crisis is clearly necessary and unavoidable, the path to be taken is neither that of resilience nor that of $i r$ reversible deformation. Rather, efforts must be focused on the deep and structural causes of constitutional law's current crisis, to avoid that the corrections -formulated on the basis of the emergency- wreak worse damage than the actual evils.

${ }^{2}$ G. Agamben, State of Exception, trans, Chicago, Chicago Univ Press, 2005, passim. 


\section{THE DECLINE OF CONTEMPORARY EUROPEAN CONSTI- TUTIONALISM: «RETURN TO THE STATUTO»?}

If we wish to strike at the real core of the crisis of contemporary constitutionalism, in my view the phenomenon that we are witnessing may be defined as a progressive flexibilisation of existing constitutions.

I will not use the term «deconstitutionalisation» (although it may perhaps be more appropriate), because in many cases there is no express or implied repeal. Constitutional texts remain in force - indeed, they proliferate; and what disappears is the «normative added value» that characterizes constitutions, or at least contemporary «rigid» constitutions.

To reprise an expression from Italian history, it may be said that we are witnessing a sort of «return to the Statuto» ${ }^{3}$, i.e. the loss of the distinctive trait of post-totalitarian, post-WWII constitutions as against liberal constitutionalism: their superiority to the law and to the acts undertaken by public powers.

Post-totalitarian constitutionalism is based on the notion that there is a superior law (a higher law) to ordinary laws and administrative acts ${ }^{4}$. Therefore, liberal rule of law was not only enriched with an additional hierarchical rank, but rather with a new dimension, different and superior to legality: constitutionality. All public powers, including the Parliament, must observe this insurmountable «measure».

I believe that these qualities, that have characterized post-WWII national constitutions over recent decades, have been showing increasing signs of failure; there has been a growing adjustability of constitutional norms as against other (not necessarily only public) sources of law.

This process has multiple causes, which are not always of equal significance. In any case, all predated the 2008 financial crisis and are therefore logically independent of it. As I have already mentioned, in many cases the crisis was an «amplifier», a «trigger», but since a scientific consideration of the matter should strive to identify the root and incidental causes of a given phenomenon -and seek to distinguish between the two- I will discuss at least some of the structural causes.

First, I will describe some of the effects of the «flexibilisation» of our constitutions, focusing on two areas which are used to identify the content of constitutions: the form of government and the form of state.

${ }^{3}$ This expression is taken from the title («Torniamo allo Statuto») of an article published by Sidney Sonnino, a Deputy of Parliament of the Destra Storica party, on 1 January 1897 in the publication entitled Nuova Antologia. In that article, he expressed the hope of returning to observe the Statuto, the first constitution of the Italian Kingdom issued in 1848 and which, unlike the current republican Constitution of 1948, is flexible, i.e. is freely amendable by ordinary legislation.

${ }^{4}$ Whether, on a Kelsenian perspective, this law is deemed superior in legal terms as Grundnorm within a hierarchical legal system, or whether in Schmittian terms it is considered a political act of supreme decision on the unity of the State, or, finally, whether it is considered the «supreme law of the land», as per the North American legal tradition. 
My analysis will not explicitly extend to the other typical area of constitutional law, i.e. the protection of fundamental rights. This issue would require a different analysis. However, it may be recalled that the protection of fundamental rights depends not only on the Charters which expressly enshrine them, but also on the constitutional limitation of public powers; in this sense, the following observations will also be relevant to rights.

\section{IMPACT ON PARLIAMENTARY FORMS OF GOVERNMENT}

\subsection{Flexibilisation of the system of legal sources}

What constitutionalists mean by form of government is surely, by definition, the least rigid part of a constitution. In relation to the core of this notion, i.e. the relationship between Parliament and Government, jurists concur that the Italian «founding fathers» only established a very concise and essential statement of some fundamental «boundaries», leaving ample space to conventions, customs and constitutional practice ${ }^{5}$.

However, one aspect of the form of government that has always been well-defined in the Constitution is the "system of legal sources», i.e. the regulation of the «form» of parliamentary laws, of legislative initiative and of the procedure for approving legislation, of all other primary legal sources within the system (the principle of the «limited number» of primary sources) and, finally, of the Government's power to issue primary and secondary legislation. Legal scholarship has always supported this observation with the conviction that studying the system of legal sources is one of the few indicators that can shed light on the actual evolution of a country's form of government, especially for those having parliamentary systems ${ }^{6}$.

As may be known, these «norms on norm-making» are the only part that Hans Kelsen deemed worthy of being called a real «constitution», as they concern the procedures and conditions for a legislative act to be valid and thus existent, in Kelsenian terms.

Therefore, especially if a temporal perspective on this part of our constitution is adopted, I believe it possible to state that much regulation on the system of primary legal sources may now be considered «deconstitutionalised».

The two clearest examples of this are the decree-law and the legislative decree; both of these legislative powers of the Government have in practice evolved well beyond the schemes establishing them (in Articles 76 and 77 of the Constitution).

${ }^{5}$ L. Elia, Governo (forme di), XIX, Milan, Giuffrè, 1970, pp. 634 et seq.

${ }^{6}$ For an account of the influence of the Constitutional Court on the form of government by means of its case-law on sources, see A. Simoncini, Corte e concezione della forma di Governo, in Corte costituzionale e processi di decisione politica acura di V. Tondi della Mura, M. Carducci, R.G. Rodio, Turin, Giappichelli, 2005, pp. 239 et seq. 
In practice, since 2008, this deviation has not undergone any particular qualitative evolution.

\begin{tabular}{|l|c|c|c|c|c|c|c|c|}
\hline & \multicolumn{2}{|c|}{$\begin{array}{c}\text { XIII (from } \\
9 / 5 / 1996 \text { to } \\
29 / 5 / 2001)\end{array}$} & \multicolumn{2}{c|}{$\begin{array}{c}\text { XIV (from } \\
\text { 20/5/2001 to } \\
27 / 4 / 2006)\end{array}$} & \multicolumn{2}{|c|}{$\begin{array}{c}\text { XV (from } \\
28 / 4 / 2006 \text { to } \\
28 / 4 / 2008)\end{array}$} & \multicolumn{2}{|c|}{$\begin{array}{c}\text { XVI (from 29/4/2008 } \\
\text { to 13/03/2013) }\end{array}$} \\
\hline & Total & $\begin{array}{c}\text { Monthly } \\
\text { average }\end{array}$ & Total & $\begin{array}{c}\text { Monthly } \\
\text { average }\end{array}$ & Total & $\begin{array}{c}\text { Monthly } \\
\text { average }\end{array}$ & Total & $\begin{array}{c}\text { Monthly } \\
\text { average }\end{array}$ \\
\hline Laws & 906 & 14.93 & 686 & 11.64 & 112 & 4.66 & 384 & 6.79 \\
\hline Leg. decrees & 378 & 6.23 & 288 & 4.89 & 114 & 4.74 & 223 & 3.94 \\
\hline Decree-laws & 204 & 3.36 & 216 & 3.66 & 48 & 2 & 118 & 2.09 \\
\hline
\end{tabular}

Regardless of the reference to the "current exceptional situation of international crisis and market instability» made in the preamble of the decreelaws adopted during the crisis ${ }^{7}$, they are similar in content to many urgent decrees issued before.

It is equally certain that on this front, the current government has even managed to give rise to new forms of «violation» of the constitutionallyestablished system of legal sources.

By way of example, I will mention only one significant episode. The «salva-Italia» («Italy-saving») decree-law imposed an extraordinary tax on the financial activities covered by the «scudo fiscale» («tax shield»). The tax had to be paid by 16 February 2012, and the payment procedure had to be established by the Italian Revenue Agency with an official decision. However, the Agency published this procedure only on 14 February 2012, two days before the deadline; in light of the (justified) panic of banks, intermediaries and other subjects affected by the tax, the Ministry of Economy, which in Monti's technical government coincided with the President of the Council of Ministers (until Minister Grilli took over), published the following communication on 15 February:

«The Ministry of Economy and Finance states that in light of the objective operational difficulties expressed by the financial intermediaries obliged to pay the tax on the activities covered by the tax "shield" [...], the established deadline of 16 February will be postponed, with the earliest possible legislative provision.

This provision will state that the payments that are not made before the date of the entry into force of the prorogating provision will not constitute a payment violation.» (emphasis added).

Therefore, a press release «having force of law» (one could say!), from which two significant pieces of information emerge: first, the notion of the

${ }^{7}$ See for example the Decree-Law 22 June 2012 No. 83 «Urgent measures for the Country's growth». 
legislative amendment being inserted in the «earliest possible legislative provision» appears almost to prove the absolute interchangeability of all primary normative instruments available to the government (which in turn confirms the old image of the decree-law as a «speed train» to which an indefinite number of wagons may be attached). The second is the pledge to "disapply" the fiscal penalties for failure to pay taxes; a pledge which the government took by means of a press release.

The crisis is hardly relevant here; the notion that the Government is the «lord of the sources» (to recall the image portrayed by Marta Cartabia at a recent convention) ${ }^{8}$, a notion that is increasingly gaining strength, responds to an evolutionary trend present in many European forms of parliamentary government, with an increasingly pre-eminent role of the executive over the legislative. This may not be so in the United Kingdom, where it has indeed always been true, but rather in other parliamentary or, to an even greater extent, semi-presidential governments.

The trend is to reverse the fundamental assumption of parliamentary regimes that the Parliament is the sole body with legislative power, and the Executive may exercise such power only in exceptional cases: today, we increasingly see Governments that enjoy parliamentary majorities, usually guaranteed by strongly majoritarian electoral systems, and wield a sort of undifferentiated primary normative power, free from limitations and procedures, and which can assume the form most suitable or appropriate to individual decisions (decree-law, legislative decree, bill, secondary legislation of deregulation).

What caused this evolution?

It is impossible to undertake a detailed analysis here; I will limit myself to some notes.

First, it is intrinsically difficult for rigid constitutions to ensure the observance of their provisions on issuing laws and acts having force of law; we might define this as an inevitable weakness of the constitutional review of legislative acts for formal flaws. Indeed, unlike substantive flaws, which affect one or more norms, formal flaws act like a «cluster bomb»: the parent measure's unconstitutionality is transmitted in a chain reaction to all the norms approved on its basis, which are usually copious and important (such as the decree-laws on which entire financial operations are based ${ }^{9}$ ). G. Zagrebelsky realistically observes that constitutional judges very often hesitate to

${ }^{8}$ M. CARTABIA, Il governo signore delle fonti? Introduzione, in Gli atti normativi del governo tra Corte costituzionale e giudici, a cura di M. CARTABIA, E. LAMARQUE, P. TANZARELla, Torino, Giappichelli, 2011, pp. 9 et seq.

${ }^{9}$ On this last point see N. LuPo, L'omogeneità dei decreti-legge (e delle leggi di conversione): un nodo difficile, ma ineludibile per limitare le patologie della produzione normativa, in Scritti in memoria di Alessandra Concaro, a cura di G. D'EliA, G. TiBeri, M.P. Viviani Sclein, Giuffrè, Milano, 2012, pp. 419 et seq. 
annul norms with only formal, and not also substantive, flaws; and they only annul formally flawed laws if they are also substantively flawed ${ }^{10}$.

However, I believe that there are two other, more structural, reasons, that explain this flexibilisation.

First, the growing value of the «time» factor in lawmaking.

The case of decree-laws in Italy is a clear example: today, timeliness in lawmaking is usually more important than its content. To reach a late decision is very often tantamount to not deciding.

It is undeniable that many of our parliaments' procedural rules are still fundamentally linked to the model of the principal normative act: law enacted by Parliament. This must be approved article by article, subjected to a final vote, and examined by a commission and then by the entire House. This basic structure, inherited from liberal parliaments, was transposed unchanged into our Constitution and into Parliament's internal regulations.

The structure certainly worked well as long as the function of Parliaments was mainly one of discussion (within consociational political contexts), but from a certain moment -the great geopolitical changes of the early $1990 \mathrm{~s}$, and the introduction of obligatory policies of economic convergence at European level during the same period-that is, since the dialogue function was replaced by the notion of a «deciding democracy» ${ }^{11}$ in which it became necessary to ensure efficiency and coherence in government directions especially on decisions of an economic nature, this structure began to show its limitations. Decree-laws, capable of immediately entering into force, became the only instrument available for timely decisions.

It cannot be denied that in recent years, the Constitutional Court has shown greater sensitivity to the issue of decree-laws and formal reviews for constitutionality; judgments no. 171 of 2007, 128 of 2008 and especially 22 of 2012 display a significant change in approach compared to the acquiescence previously shown, especially in relation to the «manifest extraneousnessı of modifications made by Parliament. However, the difficulty of voiding the entire decree-law and delegating legislation for failure to fulfil the conditions established in Articles 76 and 77 of the Constitution is still well-entrenched. Indeed, the practice of issuing «urgent» decrees, which is now - paradoxically - the principal lawmaking procedure in Italy, is not substantially affected by these judgments ${ }^{12}$.

${ }^{10}$ In this connection, although considered less effective, see the pre-emptive review for constitutionality (such as that operated by the French Conseil Constitutionnel), performed prior to the law's entry into force and appears to be more incisive (for an account of the French experience see P. PASSAGLIA, L'invalidità procedurale dell'atto legislativo: le esperienze italiana e francese a confronto, Turin, Giappichelli, 2002, passim).

${ }^{11}$ This is the expression used by the then President of the House of Representatives Luciano Violante, in the Premise to Modificazioni al Regolamento della Camera dei deputati, Camera dei Deputati, Rome, 1998, p. XI.

${ }^{12}$ A. SPERTI, Il decreto-legge tra Corte costituzionale e Presidente della Repubblica dopo la seconda svolta, in Gli atti normativi del governo tra Corte costituzionale e giu- 
However, I wish to highlight that the meagre tenure of the constitutional system of legal sources is a phenomenon that does not concern only national constitutional law; a similar trend is taking place on the European level.

It is indeed clear that some of the most significant recent decisions at European level -such as the adoption of the European Stability Mechanism and the related European Stability Facility-were taken by means of international treaties between some of the EU members, rather than through usual sources of European law such as regulations and directives.

As highlighted by Bruno De Witte ${ }^{13}$ with reference to a recent important case, during an Ecofin meeting, following the approval of a European regulation to create the European Financial Stabilisation mechanism, the European Council of Ministers of Economy and Finance «changed register» and the 17 Eurozone countries adopted a decision obligating those very states to create a European Financial Stability Facility. This decision was entirely foreign to European law and taken on the basis of a measure of international law, and was then named Decision of the Representatives of the Governments of the Euro Area Member States Meeting within the Council of the European Union.

As may be known, pursuant to this measure, other EU Member States adopted, approved and ratified additional international treaties, always beyond the scope of European law (although their application and their observance was ensured by EU bodies such as the Commission and the Court of Justice): the ESM Treaty (comprising 17 upon 27 Member States) and the Fiscal Compact (25 out of 27 Member States).

As De Witte recalled, this tendency too, of failing to observe the system of sources established by the EU treaties, is not a recent occurrence that can be ascribed to the crisis.

For example, one may consider the Schengen Treaty of 1985 and 1990, or the Social Policy Agreement, concluded as a treaty alongside the Maastricht reform. Both of these measures excluded the United Kingdom.

The entire so-called -before the Amsterdam and Lisbon Treaties- Third Pillar constituted an area of essentially international/European law existing alongside European law.

In this case too, the crisis cannot be considered a specific cause, but rather only an intensification of a phenomenon that was already unfolding: the low tenure of the system of European sources.

What are the reasons for this? A great deal of space would be required for an exhaustive answer. However, there are surprising analogies with the reasons found within the Italian constitutional system.

dici, a cura di M. Cartabia, E. Lamarque, P. Tanzarella, Torino, Giappichelli, 2011, p. 15 et seq.

${ }^{13} \mathrm{~B}$. De WitTe, The use of International Law in the framework of the Economic Union: Reasons and Consequences (unpublished). 
First, at the European constitutional level too -a level at which, as may be known, supranational and intergovernmental «characters» have always had to confront each other- once the supranational nature had reached its highest fulfilment with the creation of the Euro and the enlargement to 27 Member States, a powerful intergovernmental counter-force emerged. Indeed, executive power in Member States are regaining a great deal of strength despite efforts to counter this force with a more thorough realization of the principle of subsidiarity.

But there is a further issue -again, raised by De Witte- that is naturally continuous with the causes of the great proliferation of urgent decree-making in Italy: why did the Eurozone states, on the same day that the EU Council adopted a regulation on the European Stability Mechanism, adopt the European Financial Stability Facility with an act of international law?

As may be known, the latter is an executive agreement, i.e. an immediately enforceable international agreement that enters into force when signed by governments, without need for ratification on part of national parliaments; with this type of agreement, a private company under Luxembourgish law was created ${ }^{14}$, the 17 Member States of the Eurozone being its shareholders. Immediately after, the same states adopted a series of agreements to establish their voting rights within the company.

What was the purpose?

To effectively guarantee payment of the Eurozone states' debts, it would have been necessary to amend the Lisbon Treaty (to overcome the ban established in the European treaties on European institutions guaranteeing for or taking on the debts of Member States); therefore, it would have been necessary to launch a long and complex Treaty amendment process, according to a timeframe that the financial markets would never have observed. Yet, it was necessary to provide an immediate response to the markets' requirements; hence the need for a legal act that could immediately enter into force, and to create a «private» entity -belonging to the states- that could operate from the very next day. As may be known, it was only after this immediate act that the abovementioned amendment to the Lisbon Treaty was adopted; and, later, that the treaty on the European Stability Mechanism, which stabilized and inherited the European Financial Stability Facility, was created.

As further confirmation of the convergence of European and national constitutional law in terms of the «flexibilisation» of systems of legal sources, the recent European Court of Justice judgment in Pringle (Case C-370/12) must be mentioned. In that case, the Luxembourg court had to ascertain the compatibility of Decision 2011/199/EU of the European Council of 25 March

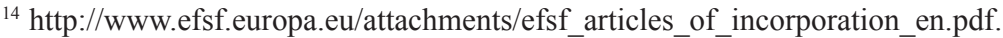


2011 with the Treaty system. The Decision amended Article 136 TFEU to enable adoption of the ESM ${ }^{15}$ following a simplified procedure.

The Court rejected the questions raised by the Irish Supreme Court and held that the Decision was legitimate. In light of the extraordinary emergency faced by Europe and of the need for interventions such as the Fiscal Compact and the ESM, there could be no doubt as to the outcome of the case. Nevertheless, many of the issues highlighted by the Irish Court raise significant perplexities. ${ }^{16}$

\subsection{Flexibilisation of the regulation of economic policy}

Another aspect of the constitutionally-established form of government which has apparently become «flexible» is that of decisions on economic and monetary policy.

I do not think that there is much need for examples in this regard; since the very beginning of the European single market, the ownership of decisions on matters of economic and monetary policy has been less and less national.

In this case too, the early 1990s are the crucial moment. The Maastricht Treaty and the decision to create the single currency, the European System of Central Banks and the genesis of the European Central Bank are the steps of a substantive «Europeanisation» of political decisions on economic and monetary matters.

Moreover, in this context too, it can be said that the «rigidity» of constitutions in granting power to national states' various organs has gradually «faded» as economies have become globalised; the urgent need for coordination and for supranational direction of economic policies is not, therefore, a phenomenon that can be ascribed to the 2008 crisis.

First with the Maastricht Treaty and its famous parameters, then with the single currency, Member States - especially Italy - began to understand

${ }^{15}$ Article 1 of Decision 2011/199 states the following:

«The following paragraph shall be added to Article 136 of the Treaty on the Functioning of the European Union:

"3. The Member States whose currency is the euro may establish a stability mechanism to be activated if indispensable to safeguard the stability of the euro area as a whole. The granting of any required financial assistance under the mechanism will be made subject to strict conditionality.".»

${ }^{16}$ Indeed, the possibility of modifying the TFEU by means of the simplified form of «decision» adopted by the Council is relevant only to modifications that do not regard Part I of the Treaty, while the provision that Eurozone Member States may introduce a «stability mechanism to be activated if indispensable to safeguard the stability of the Euro area as a whole» is, frankly, difficult to bring under Part II of the Treaty. Likewise, I find it difficult to refrain from acknowledging that this provision ends up extending the EU's competences (another condition which is excluded if the simplified procedure is to apply). Finally, I consider significant the objection that in monetary issues, the Union has exclusive competence. This excludes, therefore, Member States from concluding international treaties, while both the ESM and the Fiscal Compact are, as we know, precisely that. 
that the means through which they usually financed their internal economies (debt and devaluations) were no longer available.

Some may argue that this does not actually amount to "flexibilising" the Constitution, as it was already a consequence of Italian membership of the European Union. The situation would thus fall squarely within a normal relationship between European and internal law.

However, in this field, the economic crisis itself led to a conspicuous leap in the quality of the «supranationalisation» of economic policies.

Indeed, here too, the most significant measures adopted at the European level are not measures of European law, but rather international treaties. I shall not examine the Treaty on the ESM, but rather the other convention, between 25 of the 27 Member States of the EU, adopted to complement it the Fiscal Compact.

In this connection, two important elements must be highlighted.

First, as we have already mentioned, after Maastricht and the single currency, debt and the monetary lever had already been conclusively attracted into the sphere of European governance; only the fiscal lever remained in the hands of Member States. With the Fiscal Compact Treaty, fiscal policy too is subject to supranational coordination. The "Europeanisation" of economic policy is therefore complete.

Second, with a decidedly problematic provision in terms of legal sources, the Treaty establishes that:

«[t]he rules set out in paragraph 1 shall take effect in the national law of the Contracting Parties at the latest one year after the entry into force of this Treaty through provisions of binding force and permanent character, preferably constitutional, or otherwise guaranteed to be fully respected and adhered to throughout the national budgetary processes» (emphasis added).

But to fully comprehend the legal and institutional dynamics surrounding the implementation of this Treaty, its history must be examined.

The Fiscal Compact was adopted on 2 March 2012 and entered into force on 1 January 2013; it was ratified in Italy with Law No. 114 of 23 July 2012. The balanced-budget constitutional amendments required by the Treaty were introduced by means of Constitutional Law No. 1 of 20 April 2012 (entitled Introduction of the balanced-budget principle into the Constitution); given that the procedure for enacting a constitutional law in Italy is decidedly complex ${ }^{17}$, one may ask how was it possible to approve a constitutional law only one month after the Treaty was signed and (even!) before it was ratified and entered into force.

The answer lies not in a European or international legislative act, but rather in a simple letter, sent privately on 5 August 2011 from the then Presi-

${ }^{17}$ Article 138 of the Italian Constitution: Laws amending the Constitution and other constitutional laws shall be adopted by each House after two successive debates at intervals of not less than three months, and shall be approved by an absolute majority of the members of each House in the second $\mathrm{v}$ 
dent of the European Central Bank Jean Claude Trichet and the Governor of the Bank of Italy Mario Draghi (who later succeeded the former in chairing the ECB) to the President of the Council of Ministers Silvio Berlusconi ${ }^{18}$. In this letter, they asked Italy to «urgently strengthen the reputation of its sovereign signature» and to this end required the adoption of certain measures deemed to be absolutely undelayable (liberalisation of local public services and professional services, review of the collective bargaining system and of the labour market, anticipation of the balanced budget to 2013 through spending cuts, interventions on the pensions system, public employment expenditure cuts, a clause for automatic reduction of public deficit and monitoring local expenditure).

The letter continues:

«In light of the seriousness of the financial markets' current situation, we deem it crucial that all of the actions listed above [...] be adopted as soon as possible through decree-law, followed by a parliamentary ratification within September 2011. A constitutional amendment to make budgetary rules more stringent would also be appropriate», continued Draghi and Trichet. «There is also the need for a strong commitment to abolishing or fusing intermediate administrative structures (such as the provinces, or Province)».

Thus, it is to «implement»-to use an euphemism- this private letter, signed by two central bankers, that Italy commenced the constitutional amendment resulting in Constitutional Law No. 1 of 2012.

In this case, the flexibilisation of the constitutional system reaches a symbolic apex, if it is considered that two entirely «technical» organs, that represent the banking system and the European institutions, literally «instructed» the government and the Parliament on the way forward, even going so far as to specify the means (the decree-law and the constitutional amendment) and the timeframe within which to act.

It cannot be doubted that the amendment of Article 81 of the Constitution and related Law No. 243 of 2012 implementing the balanced budget are one of the economic crisis' most recent and significant effects on the constitutional system of powers and competences.

I do not wish to undertake here a detailed examination of this reform and its differences (however important) from the parallel amendment of the Spanish Constitution.

I will simply note that the reform confirms the trend of, on one hand, the definite strengthening of the role of the Executive in economic-financial decisions (although the creation of the Independent Budget Office in Parlia-

${ }^{18}$ For the complete letter, see Corriere.it, Trichet e Draghi: un'azione pressante per ristabilire la fiducia degli investitori, http://www.corriere.it/economia/11_settembre_29/trichet_draghi_inglese_304a5f1e-ea59-11eoting.»0-ae06-4da866778̄017. shtml? $\overline{f r}=$ correlati, 20 May $2013,2 \overline{0} 11$. 
ment may be an interesting innovation) and, on the other, the consolidation of the increasingly unavoidable link with European institutions on these issues.

\subsection{Flexibilisation of the role of the President of the Republic}

The last part of the form of government affected by flexibilisation that I wish to discuss is the President of the Republic's role. Much has been said in recent months about the President. Some commentators used the events of the last two years of Napolitano's presidency to state that in fact, we have shifted towards a «quasi semi-presidential» system; see the famous «King Giorgio» headline in the New York Times ${ }^{19}$.

Now, those who are familiar with the position of the President of the Republic within the Italian Constitution know that it is much less clearly defined than it may seem.

In particular, the constitutional space occupied by the role of the President is of «variable geometry»: in «ordinary» times, when political life carries on without particular turbulence, the President tends to fade into an almost «symbolic» figure, but in times of crisis, the President recovers all his powers which, it must be recalled, have their roots in royal powers.

For this reason, rather than only «one» President of the Republic, our constitutional system has had several different Presidents, each of whom interpreted his role in different ways.

Still, it cannot be doubted that in the five years between 2008 and 2013, Giorgio Napolitano's approach brought the constitutional role of the President well beyond the positions gained even by the most active and expansive presidencies.

I refer in particular to the appointment of Senator for life Mario Monti as head of the current Government, and to the evolution of what is traditionally defined as the presidential power to express views.

In creating the Monti government, President Napolitano appeared to appoint a veritable «President's government», setting the topics, the agenda and -it may legitimately be inferred- the composition of the Cabinet.

The crisis of the government that led to the premature end of the 16th Legislature began with the Chamber of Deputies's vote of 11 October 2011 to reject Article 1 of the General National Financial Report. The next day, President Napolitano declared that «the undeniable manifestation of severe tensions within the government and the coalition, with the consequent uncertainties on the adoption of the required or announced decisions" raised "questions and concerns having indubitable institutional impact ${ }^{20} \gg$.

${ }^{19}$ See R. Donadio, From Ceremonial Figure to Italy's Quiet Power Broker, in New York Times, http://www.nytimes.com/2011/12/03/world/europe/president-giorgio-napolitano-italys-quiet-power-broker.html?_r=1\&hp, 20 May 2013, 2011.

${ }^{20}$ Press release of the President of the Republic, 12 October 2011. 
The political situation that had emerged was completely unsustainable, in terms of international credibility; for this reason, Italy experienced what I consider to be a unique event, regardless of its inventive history of government crises: the resignation of the government, subject to a «condition precedent». On 8 November 2011, after a meeting with President Napolitano, the President of the Council of Ministers Berlusconi announced that he would resign as soon as the law on financial stability was approved. However, the credibility of the President of the Council was already too damaged; for this reason, the next day, the President of the Republic, «acting as Head of State», released a communication which is worth quoting:

«In light of the pressure on Italian government bonds on the financial markets, which today reached alarming levels, as Head of State I deem it necessary to clarify the following, so as to clear any ambiguity or misunderstanding:

1) There is no uncertainty concerning the choice of the President of the Council Berlusconi to resign from the Government which he currently leads. This decision will be effective as soon as the law on financial stability for 2012 has been approved.

2) On the basis of agreements between the Presidents of the Senate and of the Chamber of Deputies and the majority and opposition parliamentary groups, the law on financial stability will be approved in a few days.

3) Consultations will then be held immediately by the President of the Republic to solve the government crisis.

4) Therefore, shortly, either a new government will be formed, and will be capable of taking all further decisions required with the confidence of the Parliament, or Parliament will be dissolved so as to immediately commence the electoral campaign, which will take place in a brief time frame.»

This is a veritable power of «government» wielded in times of crisis. In my opinion, this is unprecedented, even in light of the varied practices hitherto followed by Italian Presidents.

The other area in which I believe that a clear «demarginalisation» of the constitutional role of the President of the Republic has taken place is his power of «free» communication (i.e. communications not made through formal expressions of opinion to the Chambers of Parliament as per Article 66 of the Constitution). In recent years, the number of official communications issued by the Quirinal has grown exponentially ${ }^{21}$. These include not only communications on strictly institutional issues - such as the abuse of

${ }^{21}$ Between April 2012 and March 2013, over 680 official press releases were published on the Quirinal's website. 
emergency decrees ${ }^{22}$, but also more general ones, on political-economic matters. While the power of communication is a clear sign of the President's «diffuse» political responsibility ${ }^{23}$, as opposed to his lack of political responsibility narrowly construed - I believe that recent practice shows an increasingly active President, fully within the circuit of political decisionmaking ${ }^{24}$, and who is capable of tangibly influencing and directing the choices made by the Government and the Parliament ${ }^{25}$. It is not a coincidence that - for the first time in the history of the Republic - the possibility of Napolitano's reelection has surfaced in these very days.

\section{EFFECTS ON REGIONALISM}

\subsection{Flexibilisation of the constitutional division of powers between cen- tral state and regions}

As mentioned above, in times of economic crisis, an evident process of flexibilisation has affected not only the form of government, but also the form of state (the relationship between the central state and local autonomies).

I believe that this context too supports my view that the causes of the current phenomena are not to be found in the crisis, but rather that the crisis led to the «explosion» of dynamics that have actually been unfolding for a long time.

The economic crisis is surely making the constitutional norms on the division of powers between the central state and the regions more flexible; and, in particular, making the boundary between state and regional powers extremely transient, if not outright uncertain, in favour of the state.

A paradigmatic example is the "social card», upon which the Constitutional Court decided in Judgment No. 10 of 2010. Due to the serious economic crisis, the state issued a measure -the social card- to grant a «purchasing card» to citizens in extremely difficult economic conditions so that they could meet at least their basic food needs.

The regions challenged the decree on the grounds that it infringed their exclusive powers in matters of social services and their financial autonomy;

${ }^{22}$ One of the most important cases is surely the press release of 23 February 2012 which summarizes the problems relating to the conversion of decree-laws into laws by including parliamentary modifications which are inconsistent with the individual decreelaw's content. The press release was «inspired» by the abovementioned Judgment No. 22 of 2012 of the Constitutional Court, which, for the first time, voided provisions inserted in a decree-law by the Parliament during its examination of the related conversion bill.

${ }^{23}$ On this issue, see, in general, the studies of M.C. Grisolia, Potere di messaggio ed esternazioni presidenziali, Milan, Giuffrè, 1986, passim.

${ }^{24}$ T. Groppi, A. Simoncini, Introduzione allo studio del diritto pubblico ed alle sue fonti, Turin, Giappichelli, 2012, p. 242 et seq.

${ }^{25}$ O. Chessa, Il Presidente della Repubblica parlamentare: un'interpretazione della forma di governo italiana, Naples, Jovene, 2010, passim. 
the latter was threatened by the fact that a restricted fund had been created for a subject that fell within the regions' competences.

The significance of this decision - and of later related ones - is that the Court explicitly acknowledged that the case concerned social assistance, and displayed awareness of how this provision contrasted with its settled caselaw against the use of restricted funds for social policies managed by the central government (e.g. nurseries). However, the Court's reasoning was equally explicit in stating that the current situation is exceptional, extraordinary and urgent «due to the situation of international economic and financial crisis that in 2008 and 2009 also affected our Country»; a crisis that thrust a part of the population in a condition of «extreme need». The circumstances are such that the state's exclusive competence enshrined in Article 117(2)(m) of the Constitution (on guaranteeing basic levels of social and civil rights), which is usually fulfilled by establishing «minimum standards and levels», may be expanded and thus provide the basis for a detailed intervention ${ }^{26}$.

When «primary rights» are involved, the state may intervene by directly granting «specific aid», and go beyond simply setting structural levels «if it is unavoidable, as in the case before us, due to peculiar circumstances and situations such as an exceptionally adverse economic situation» (emphasis added).

Thus, at a first glance, it may seem that the economic crisis is to blame for the flexibility of the state's legislative power established in Article 117(2) (m). In both its literal and logical-systematic formulation (especially in light of the power of substitution enshrined in Article 120 of the Constitution), this competence certainly does not mean that the state is granted a «passepartout», a power to intervene in all regional competences -a situation often confirmed by the very Court.

But can we really be sure of this?

Or has the flexibility introduced by the 2001 reform been a «structural» element of the state/region division of powers from the very beginning?

By way of example, I will limit myself to mentioning «cross-cutting» issues (such as the environment, competition, basic levels of assistance, etc.), in relation to which the Court has always acknowledged the state's power to «intervene» in regional matters, albeit only on certain aspects.

The issue of the so-called «chiamata in sussidiarietà», or flexible subsidiarity, through which great elasticity in the division of powers is recognized.

The alternating processes of "dematerialisation" and «rematerialisation» in allocating powers, that inevitably led to an expansion of the competences of the central state as against the periphery ${ }^{27}$.

${ }^{26}$ E. Longo, I diritti sociali al tempo della crisi. La Consulta salva la social card e ne ricava un nuovo titolo di competenza statale, in Giur. cost., 1, 2010, p. 164 et seq.

${ }^{27}$ R. Bin, F. Benelli, Prevalenza e «rimaterializzazione delle materie»: scacco matto alle Regioni, in Le Regioni, 6, 2009, pp. 1185 et seq. 
And we cannot fail to mention the case-law of European derivation that, since Judgment No. 126 of 1996, has constantly affirmed that "in derogation from what has been said on the observance of the internal constitutional framework of powers, European law may, for reasons related to the European Union's organization, legitimately establish its own implementing forms. Therefore, national law that derogates from the framework of the usual constitutional distribution of internal powers, with the exception that fundamental and mandatory constitutional principles must be observed".

Therefore, also in respect of the social card, the crisis may have exacerbated the symptoms of the ongoing disease, but the cause of the pathology is to be found elsewhere. Where? Again, the issue appears very complex; I believe that mainly two factors are decisive.

The first factor is of a technical-formal nature; the very technique of dividing powers «by subject» (exclusively and concurrently) has shown an intrinsic flexibility, due to its inevitable «jurisdictionalisation». When the spheres of power are distinguished by means of lists of objects, values, functions, subjects, these are affected by the inevitable semantic «flexibility» of any legislative provision and, ultimately, shift the real definitional power to the final judge of competences, the Constitutional Court ${ }^{28}$. A recent interesting example is that of the cuts on expenditure for the regional political system, imposed by the «local authority-saving» decree-law (decreto «salvaenti» $)^{29}$. A judgment issued by the Constitutional Court held that all regions must observe the decree ${ }^{30}$.

The second factor is political: to be able to function, a composite state -whether federal or regional- presupposes a real «physiological» difference between local and national levels of political direction.

By «physiological» distinction, I mean that in a composite state, differentiating between the centre and the periphery yields positive results when the differences between localising and centralising pressures are related to actual political-cultural differences and a general shared constitutional framework; thus, when political-institutional, and not only judicial, tools exist for the resolution of any conflicts that may arise.

This position was expressed in the famous Federalist Paper No. 10, in which James Madison himself warned against factionism as a fatal flaw of democracy, and stated that a large federal republic would be the antidote to this very risk ${ }^{31}$.

${ }^{28}$ As noted by S. Calzolaio, Il cammino delle materie nello stato regionale, Turin, Giappichelli, 2012, p. 289: «paradoxically, the reaction to the fragmentation of competences has led to a situation in which the State has been granted more competence, in some sectors, than it actually wishes to exercise: thus, a dissociation takes place -for example on the subject of the environment- between substantially absolute entitlement to the subject and "discretionary" attribution of the legislative competence to regions»).

${ }^{29}$ Decree-law of 10 October 2012, No. 174.

${ }^{30}$ Judgment No. 198 of 2012.

${ }^{31}$ On this point, A.J. Bellia, Federalism, Aspen Publishers, 2011, p. 18. 
Without one of these two elements (difference or unity), the system cannot find a balance between centrifugal and centripetal forces; the history of all composite state systems shows that the centralistic force ultimately prevails, to the detriment of local autonomies.

The case of Italy is paradigmatic. We experienced a first period (1970s1990s) in which regionalism was dominated by national parties and was substantially the same as the selection process used by the national political classes. Regions were not the "gymnasiums» for the creation of a new and different political class, as had been envisaged by the constituent fathers; rather, they were local «segments» of a unitary political career, which was ultimately managed by the strength and centrality of national parties. This phase was followed by another, starting from the 1990s, in which national parties suffered a crisis and «hyper-autonomist» forces emerged to question the basic constitutional framework within which regionalism had developed (the contemporary idea of the confederation between the four northern regions is but the most recent step in this direction).

What do these two stages have in common? It is the push to strengthen the «centre»: in the first stage, this occurred due to the absence of differentiation; in the second, to an «excess» of the same. The economic crisis has thus filtered into the crisis of regionalism, which has deep roots, further «exacerbating» tensions especially by placing the financial crisis of the social state at the centre of debate.

Indeed, we should not forget that state finances' risk of default is having a dramatic effect especially on the cuts to public health expenditure, which, as may be known, constitute a very significant proportion of regional budgets.

\section{THE ECONOMIC CRISIS AND DEMOCRACY}

\subsection{Loss of trust in democratic institutions}

Above, I have argued that the most evident elements of crisis in our constitutional system of powers are to be ascribed to a structural decline and not to the economic emergency.

In this second part, I wish to highlight some factors of the crisis which I believe are to be attributed specifically to the economic-financial crisis that has been affecting the world, and therefore Europe, since 2008.

My argument can be summarized thus: since 2008, citizens have been progressively and inexorably losing faith in the capacity of democratic institutions to represent and defend the collective interests for which they were created.

In other words, we are witnessing a real collapse in the "reliability" of public powers, despite the fact that these are subject to constitutional discipline and are democratically legitimated. 
It is almost as if constitutional representative democracy, the political form created after the totalitarian experiences of the last century, can no longer ensure a true correspondence between "governors and governed".

To illustrate my theory, I will examine some empirical data gathered by Eurobarometer in July $2012^{32}$.

Figure 1 shows the trend in the opinion of the national economic system: a heavily negative opinion as from the economic crisis of 2008 is evident, and, I would say, predictable.

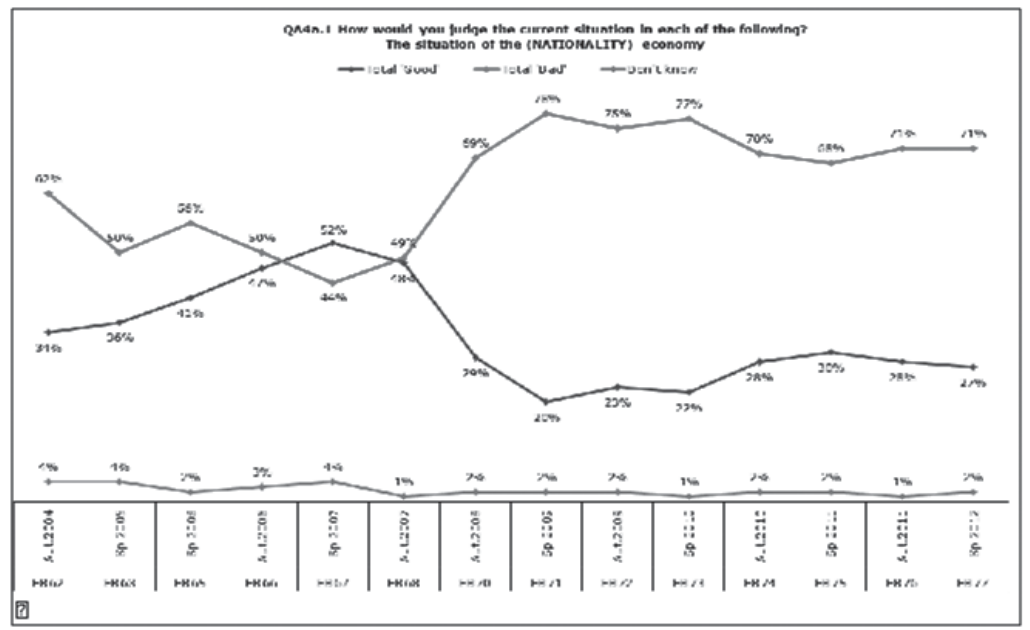

Figure 1 (Source: Eurobarometer)

However, I believe that the judgment on the current situation divided by countries, shown in Figure 2, is much more surprising and significant.

${ }^{32} \mathrm{Http}$ //ec.europa.eu/public_opinion/archives/eb/eb77/eb77_en.htm 
QA4a.1. How would you judge the current situation in each of the following?

The situation of the (NATIONALITY) economy

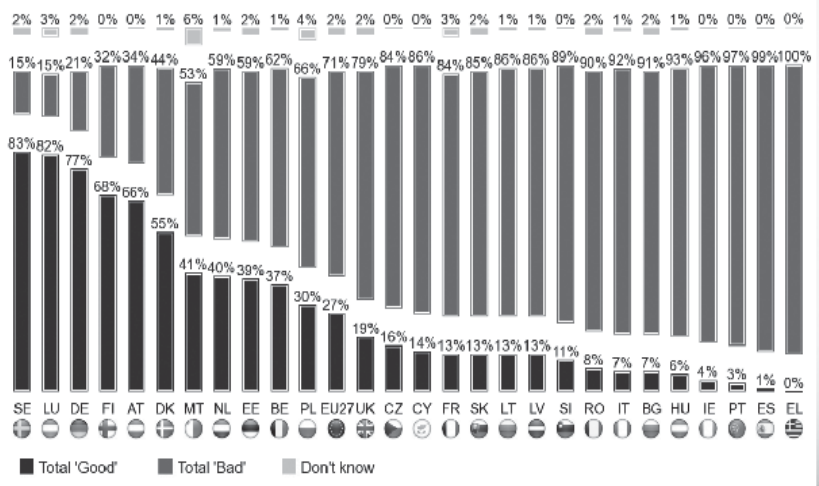

Figure 2 (Source: Eurobarometer)

The current differences between the Member States of the European Union in evaluating the economic situation are startling.

In Sweden, Luxembourg and Germany, over two thirds of the population believe that the situation is excellent. In any case, in Finland, Austria and Denmark over half the population believes that the situation is entirely good.

But this happens only in 6 states out of 27; in the remaining 21 upon 27, the exact opposite is true.

And if we consider the negative part of the graph, in 17 out of 21 states, over two thirds of the population believe the opposite; that is, that the situation is entirely negative.

We are thus before a divided and unbalanced Europe on the issue of the economic-financial crisis; a Europe in which the general aggregate negative opinion ( $71 \%$ «total bad») derives from the arithmetic average between three states with an enthusiastic opinion and nine states in which discontent exceeds $89 \%$ !

Therefore, a first conclusion that can be drawn from these examinations is that the crisis definitely does have an impact, which however is not the same for everyone.

The immediate consequence of this opinion is the decrease in trust in national and European institutions.

Figure 3 shows the aggregate trend from 2004 to today. 

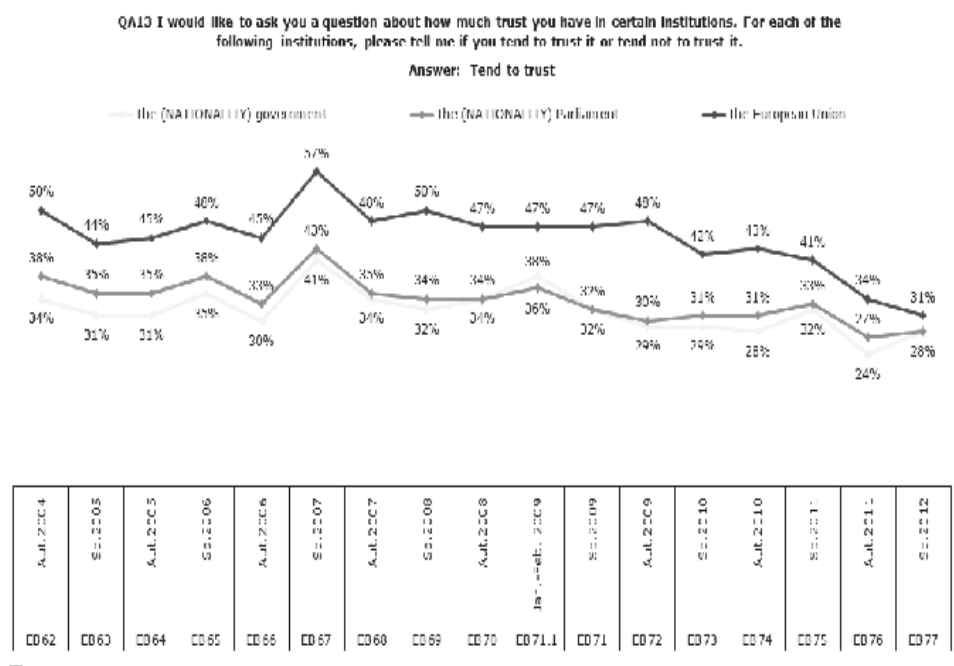

[?

Figure 3 (Source: Eurobarometer)

As may be seen, trust in European institutions has always been higher than trust in national parliaments and governments, peaking in spring 2007 (when the Union enlarged to 27 Member States), while from the beginning of the economic crisis, in 2008, a slow decline began, until 2011 (in five years, seven points were lost), to collapse between 2011 and spring 2012 (in just over a year, ten percentage points were lost). There was a substantial convergence with the levels of trust (or rather, mistrust) in national institutions.

In other words, today, two-thirds of European citizens lack trust in European and national institutions.

If we consider some individual country data, the results are alarming:

For example, Italy: 


\section{Italia}

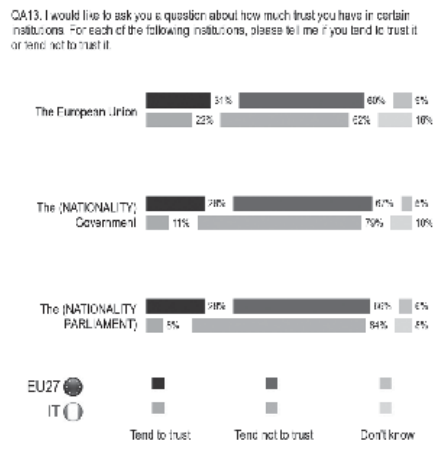

$79 \%$ of interviewees does not trust the Government, $84 \%$ does not trust the Parliament; but the news that $62 \%$ does not trust European institutions is truly surprising, in light of the fact that in 2004 trust in European institutions exceeded $70 \%$.

But let us examine the data on other European countries: Greece, Spain, Germany, Luxembourg, and Finland.

\section{Grecia -}

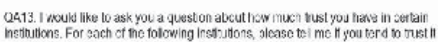
nethutions. For anch
a berd not lo trusti:
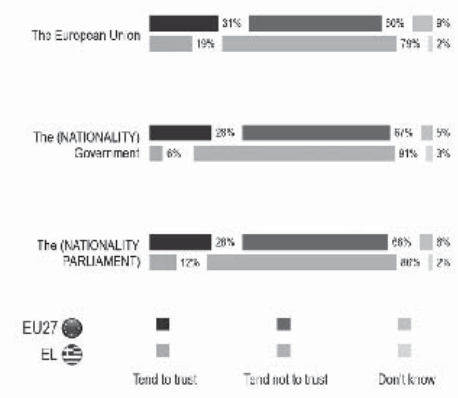
PARUAMENT 


\section{Spagna}

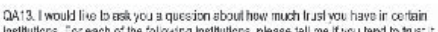
insthuticns " $C$ each of the tolowirg insthuticns please tell ne if you tent to vus: : tr tend nal to zustit
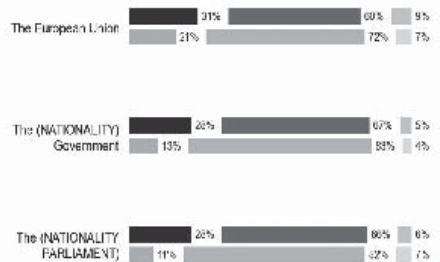

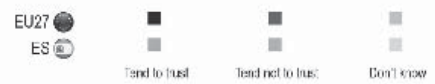

\section{Germania}

Q.913. I would lise to ask you a question about how much trust you have $n$ cerlein institut ons For each of the follzwirg instilut ons, please tell me if you lend to it.st it or tend not 00 trustit.
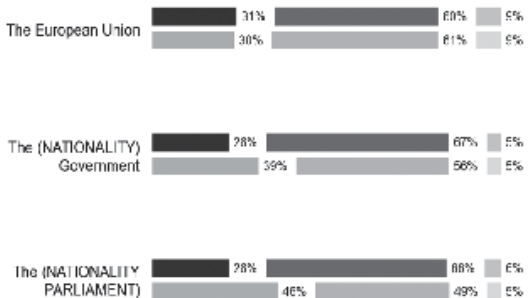

\begin{tabular}{|c|c|c|c|}
\hline EU27 & ㅁ. & 口 & 무 \\
\hline $\mathrm{DE} O$ & 미 & 口 & 무 \\
\hline & Tend to irust & Tend not to trus1 & Don't knCW \\
\hline
\end{tabular}




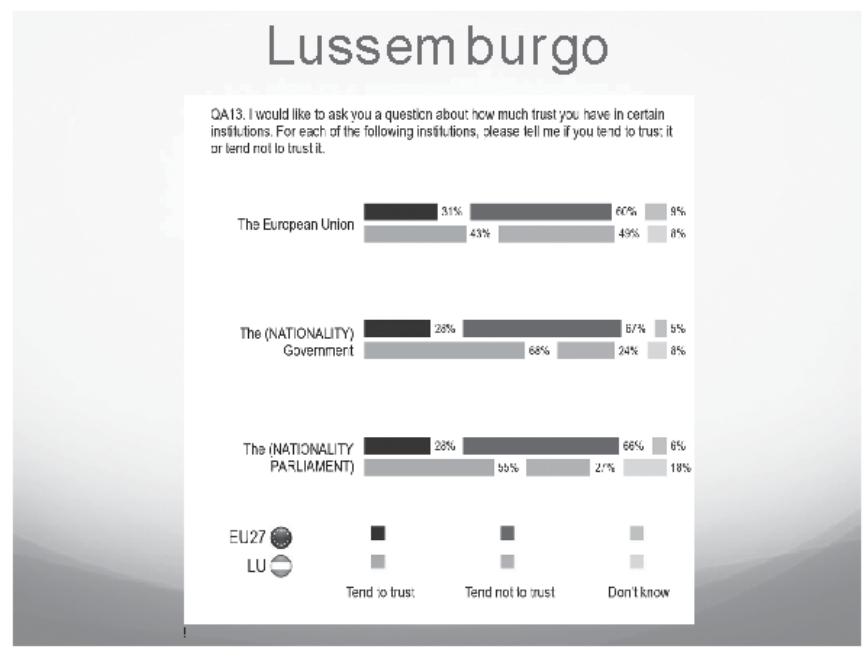

\section{Finlandia}

QA13. I would like to ask you a question about how much Irust you have in certain institutions. =or each of the following institutions please tell ne if you tend to trust $t$ or tend not to trust it
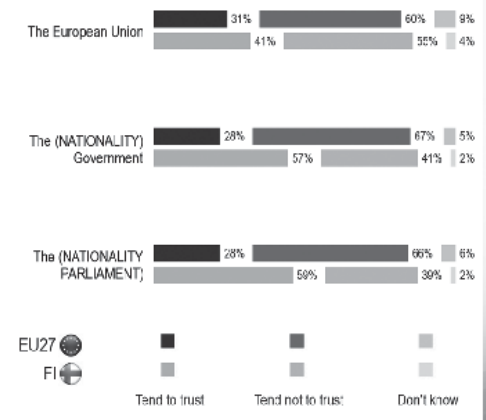

Two key observations may be drawn. ity.

First, in the opinion of citizens, all public institutions have lost reliabil-

However, whereas this observation may be considered structural in relation to national institutions before the crisis, I believe that it is possible to state that the «disaffection» for European institutions is an entirely new phenomenon. The rejection of the Constitutional Treaty certainly revealed difficulties and differences within the European Union on fundamental questions 
such as its overall structure and nature. But at least on the technical level, European institutions had always enjoyed a relatively grater positive opinion than that on national institutions. Today, this is no longer the case; European institutions, accustomed to the technical strength of their decisions, must face the problem of regaining credibility and reliability, just like national institutions.

The second observation appears to be a paradox.

In the countries where the economic situation is considered better (Germany, Sweden, Luxembourg), citizens trust their own government and parliament more than they do European institutions; this means that the positive conditions of their economy are mainly attributed to national, and not to European, institutions.

Instead, in those countries where the economic situation is considered bad, citizens have very little trust in institutions in general, but they have more trust in European institutions than in their own governments and parliaments.

Therefore, Euroscepticism as a general attitude is growing, but, paradoxically, it grows more where the situation (economically at least) is better; this confirms that in these cases, there is greater trust of national institutions rather than European ones.

This data surely cannot be a source of comfort for Brussels institutions.

\section{CONCLUSION}

The current crisis as an opportunity to rethink the foundations of legal-constitutional systems?

It could be said that this article has painted too pessimistic a picture of the tenure of constitutional democracies, due to its emphasis on structural factors of crisis that were exacerbated by new shocks due to the economic-financial crisis. It could also be stated that the present age, if no longer the age of constitutions -destined to be obsolete- is however the great age of constitutional judges, of constitutional (especially supranational) courts, which remain the bulwark that defends the law against public power, which has always sought to reject all fetters.

There is no doubt that the judicial source of constitutional law is increasingly substituting itself to political sources, but it would be a serious mistake to think that the concrete implementation of constitutional law is of concern to judicial power alone.

Indeed, while in the context of the protection of subjective constitutional rights (Modugno) it is certain that judges have significant power and are usually more effective than the «rights policies» that have often been invoked (Weiler), in the context of the limitation of powers vis à vis fundamental freedoms, or in of the definition of powers, the role of judges is extremely weak. It is sufficient to examine how the Italian Constitutional Court «was 
subjected to» the constitutional reform of 2001 -on the powers of the state and regions- and unwillingly found itself in the position of supplementing the absence of implementing legislation with its own case-law, which was often perceived as oscillating and debatable.

Reflecting on the crisis of trust in European- and national-level political institutions brings us back to the first part of our analysis. Indeed, there is a commonality between the loss of «rigidity» of national and European constitutions and the low trust in the circuit of political decision-making overseen by those Constitutions.

In this connection, it is necessary to recall what Alessandro Pizzorusso effectively clarified ${ }^{33}$ : the «legal superiority», in hierarchical terms, of post-WWII rigid constitutions has always been in «the expression of a more intense political will contained in these documents, as against ordinary legislation» (emphasis added); that is, constitutions have always enjoyed a sort of political added value because they express choices, values and a common good upon which social coexistence may be constructed.

Therefore, a crisis in «trust» cannot avoid having repercussions, sooner or later, on the legal «superiority» of constitutional sources.

\section{BIBLIOGRAPHY}

Agamben, G., State of Exception, trans, Chicago Univ Press, Chicago, 2005. Angelini, F. - Benvenuti, M. (a cura di), Il diritto costituzionale alla prova della crisi economica. Atti del Convegno di Roma, 26-27 aprile 2012, Naples, Jovene, 2012.

Bellia, A. J., Federalism, Aspen Publishers, 2011.

Bin, R. - Benelli, F., Prevalenza e «rimaterializzazione delle materie»: scacco matto alle Regioni, in Le Regioni, 6, 2009.

Calzolaio, S., Il cammino delle materie nello stato regionale, Giappichelli, Turin, 2012.

CARTABIA, M., Il governo signore delle fonti? Introduzione, in Gli atti normativi del governo tra Corte costituzionale e giudici, a cura di M. CARTABia, E. Lamarque, P. Tanzarella, Giappichelli, Torino, 2011.

Chessa, O., Il Presidente della Repubblica parlamentare: un 'interpretazione della forma di governo italiana, Jovene, Naples, 2010.

CORRIERE.IT, Trichet e Draghi: un'azione pressante per ristabilire la fiducia degli investitori, in 2011, http://www.corriere.it/economia/11 settembre 29/trichet draghi inglese 304a5fle-ea59-11e0-ae064da866778017.shtml? $\overline{f r}=$ correlati.

Donadio, R., From Ceremonial Figure to Italy's Quiet Power Broker, in New York Times, 2011, http://www.nytimes.com/2011/12/03/world/eu-

${ }^{33}$ A. Pizzorusso, Delle fonti del diritto, in Commentario al codice civile, a cura di A. Scialoja, G. Branca, Bologna-Roma, Zanichelli-Il Foro italiano, 1977, p. 11. 
rope/president-giorgio-napolitano-italys-quiet-power-broker.html? $r=1 \& h p$.

EliA, L., Governo (forme di), XIX, Giuffrè, Milan, 1970.

Grisolia, M. C., Potere di messaggio ed esternazioni presidenziali, Giuffrè, Milan, 1986.

Groppi, T. - SimoncinI, A., Introduzione allo studio del diritto pubblico ed alle sue fonti, 2nd, Giappichelli, Turin, 2012.

Longo, E., I diritti sociali al tempo della crisi. La Consulta salva la social card e ne ricava un nuovo titolo di competenza statale, in Giur. cost., 1, 2010.

LuPo, N., L'omogeneità dei decreti-legge (e delle leggi di conversione): un nodo difficile, ma ineludibile per limitare le patologie della produzione normativa, in Scritti in memoria di Alessandra Concaro, a cura di G. D’Elia, G. Tiberi, M.P. Viviani Sclein, Milano, Giuffrè, 2012.

Passaglia, P., L'invalidità procedurale dell'atto legislativo: le esperienze italiana e francese a confronto, Giappichelli, Turin, 2002.

Pizzorusso, A., Delle fonti del diritto, in Commentario al codice civile, a cura di A. Scialoja, G. Branca, Zanichelli-Il Foro italiano, Bologna-Roma, 1977.

Simoncini, A., Corte e concezione della forma di Governo, in Corte costituzionale e processi di decisione politica acura di V. Tondi Della Mura, M. CARducCI, R.G. Rodio, Giappichelli, Turin, 2005.

Sperti, A., Il decreto-legge tra Corte costituzionale e Presidente della Repubblica dopo la seconda svolta, in Gli atti normativi del governo tra Corte costituzionale e giudici, a cura di M. Cartabia, E. Lamarque, P. TANZARElla, Giappichelli, Torino, 2011.

RESUMEN: Este artículo analiza el impacto de las medidas adoptadas en el contexto de la lucha contra la crisis económica en los sistemas de gobierno en general y el italiano en particular. Concretamente, se realiza una crítica de la mutación del sistema de gobierno derivada de los mecanismos de implementación de estas medidas.

PALABRAS CLAVE: Derecho constitucional, crisis económica, medidas de austeridad, sistema de gobierno.

ABSTRACT: This article analyzes the impact of the anti-crisis mesures within the systems of government in general and the Italian case in particular. Specifically, the author critizes the mutations operated within the Italian system as the result of the implementation mechanisms of the anticrisis mesures.

KEYWORDS: Constitutional law, economic crisis, austerity measures, system of government.

Recibido: 24.07.2013

Aceptado: 02.09.2013 